\title{
CONTRIBUTIONS TO THE ANATOMY OF SOME REPTILIAN CESTODES.
}

\author{
By JEAN G. BAER, D.Sc. \\ Zoological Institute, University of Neuchâtel.
}

(With 12 Text-figures.)

HAviNG at our disposal material from various sources obtained from the intestines of monitor lizards, it appeared useful to prepare drawings and descriptions of the less known species of parasites.

\section{(a). Duthiersia fimbriata (Diesing, 1854).}

Most of our material consists of numerous specimens of Duthiersia fimbriata (Diesing, 1854), a Bothriocephalid, frequently found in monitors. As this species was obtained both from African and from Indian monitors, a comparative study of the various specimens was made in order to try and clear up the question as to the existence of two distinct species.

Before dealing with anatomical details, the history of the genus Duthiersia may be briefly recapitulated.

Valenciennes (1849) described under the name of Bothridium du varan $d u$ Nil a tapeworm from Varanus niloticus $\mathrm{L}$. This species was later listed by Diesing as Solenophorus fimbriatus Diesing spec. inq. Perrier (1873) rediscovered the tapeworms from African and from Indian monitors, and not knowing of Diesing's paper, he created a new genus Duthiersia containing two species, viz. D. expansa Perrier from Indian monitors and $D$. elegans Perrier from African monitors. The genus Duthiersia was fully justified and was accepted by Monticelli and Crety (1891) who placed it in their new sub-family Solenophorinae where it figured with only a single species, D. fimbriatus (Diesing). The Italian authors considered $D$. elegans as a synonym of $D$. expansa, the latter being already a synonym of $D$. fimbriata. The sub-family Solenophorinae has since disappeared, thanks chiefly to the work of Lühe (1899), and all authors agree with Lühe in placing the genus Duthiersia in the sub-family Diphyllobothriinae. However, much confusion has been caused through authors like Braun (1896), Lühe (1899), Shipley (1904), Klaptocz (1906), Southwell (1913) and Cholodkovsky (1914) having based their statements on material from either the African or the Indian monitors. Beddard (1917) was the first to compare the African and Indian parasites and concluded that there are two distinct species. 
$A$ priori it would seem natural that lizards inhabiting different continents should harbour different parasites. This is the case for the species of Bothridium, closely related to Duthiersia, which is found in African and Indian pythons (see Joyeux and Baer, 1927).

Our investigations have led us to an opinion already held by most authors, namely, that there is but one species of Duthiersia which occurs both in Indian and African monitors. The chief differences separating the two species are of morphological interest only, and centre in the scolex. The scolex of Duthiersia, as in that of most Bothriocephalids, is extremely variable both in size and shape, and hardly affords a reliable means for differentiating the two species. We find it impossible to distinguish the scolices from one another. All present a more or less visible posterior pore. It has been necessary to cut serial sections to reach this conclusion, for when, as sometimes happens, the scolex is contracted, the pore is pressed against the strobila where it could never be found on whole mounts. The presence of a posterior pore has been denied by most authors; however, serial sections of not more than $8 \mu$ in thickness can alone decide this point, as it is extremely rare to find a distinct pore on whole mounts.

The extreme variation of the scolex both in shape and size together with the presence of a posterior pore lead us to the conclusion that there is only a single species of Duthiersia, namely:

\author{
Duthiersia fimbriata (Diesing, 1854). \\ Synonyms: Solenophorus fimbriatus Diesing, 1854. \\ Duthiersia expansa Perrier, 1873. \\ Duthiersia elegans Perrier, 1873. \\ Duthiersia fimbriata (Diesing), Monticelli and Crety, 1891.
}

Hosts: Varanus salvator Laur., V. bengalensis Daud, V. exanthemicus Bosc., $V$. niloticus L., V. albigularis Daud.

Distribution: Southern Asia and Africa.

This species attains a maximum length of $280 \mathrm{~mm}$., the average length being about $120-200 \mathrm{~mm}$., although smaller specimens may be found; for instance, Klaptocz (1906) described adult specimens of not more than $82 \mathrm{~mm}$. in length. The width varies from $2-5 \mathrm{~mm}$. The scolex is extremely variable in shape and size as a glance at Figs. 1 to 5 will show more clearly than a lengthy description. It may be compared to two funnels joined by an intermediate band of tissue containing the main excretory vessels and the nerve stems. The edges of the funnels are frilled, giving to the whole the appearance of a flower. Both funnels open posteriorly by a minute pore, the one being situated on the ventral surface, and the other on the dorsal surface of the strobila. The pore is sometimes closely adpressed to the strobila. We have found no trace whatever of an "apical sensory organ" as described by Beddard (1917, p. 74). The width of the scolex varies from 3 to $8 \mathrm{~mm}$. The segments are usually longer than wide although we have often found adult segments wider than long. The 
muscular system is well developed, especially so the longitudinal muscle layer, which consists of a very great number of fibres forming a distinct layer $37 \mu$ thick, thus separating the cortex from the medulla. The transverse muscles are represented by very fine fibres passing in between the longitudinal fibres.
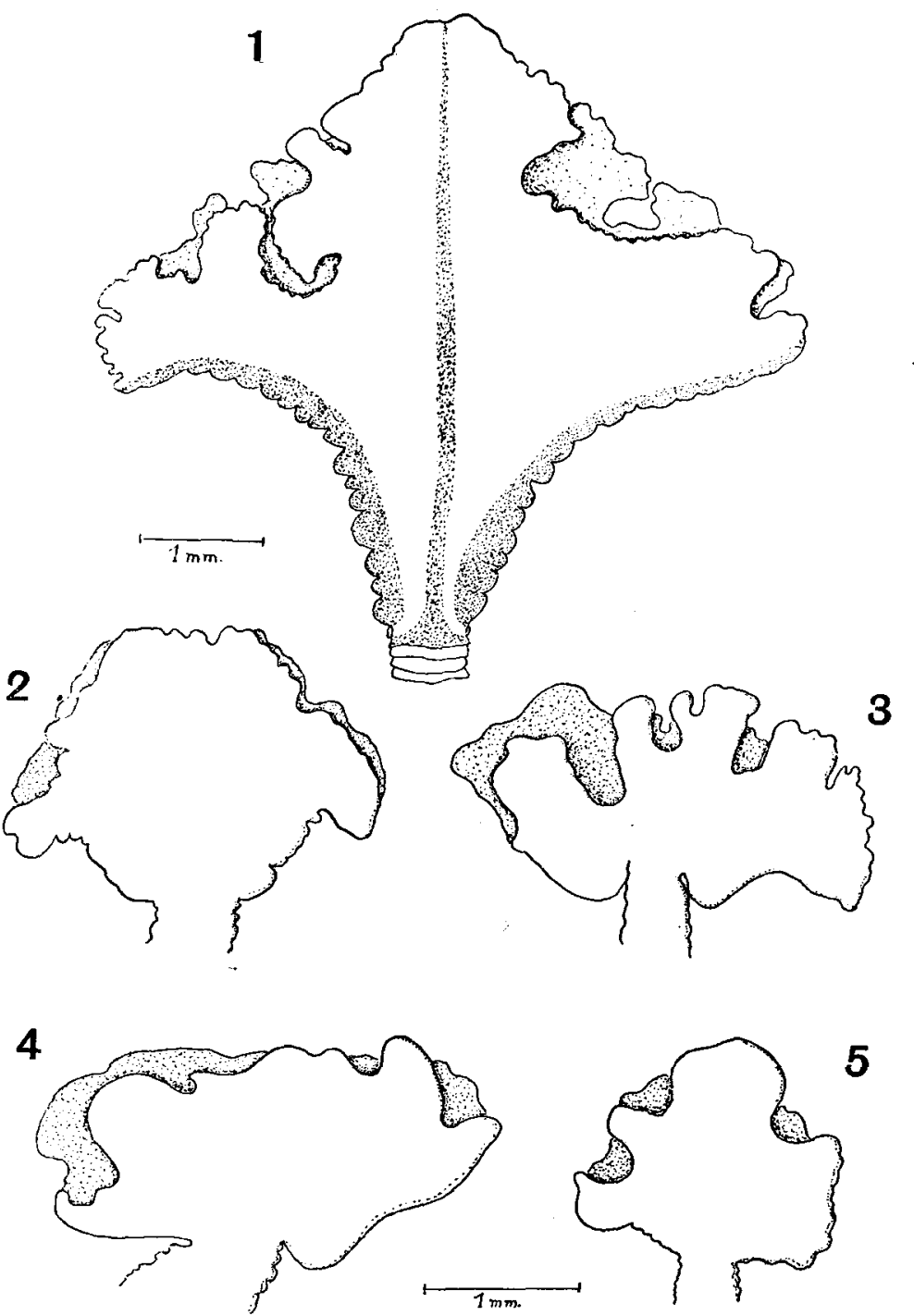

Figs. 1-5. Duthiersia fimbriata. Different scolices showing the variation in shape.

The dorso-ventral muscles are hardly visible. The excretory system is exceedingly well developed, especially in the scolex, where it forms a complicated network. The latter is in relation with the four longitudinal vessels which pass throughout the entire strobila. The two dorsal vessels, having thicker walls, are more easily visible; they are usually $40 \mu$ in diameter. The ventral vessels 
are larger and attain a maximum diameter of $130 \mu$. They are united by an intricate network of secondary vessels as often found in Bothriocephalids.

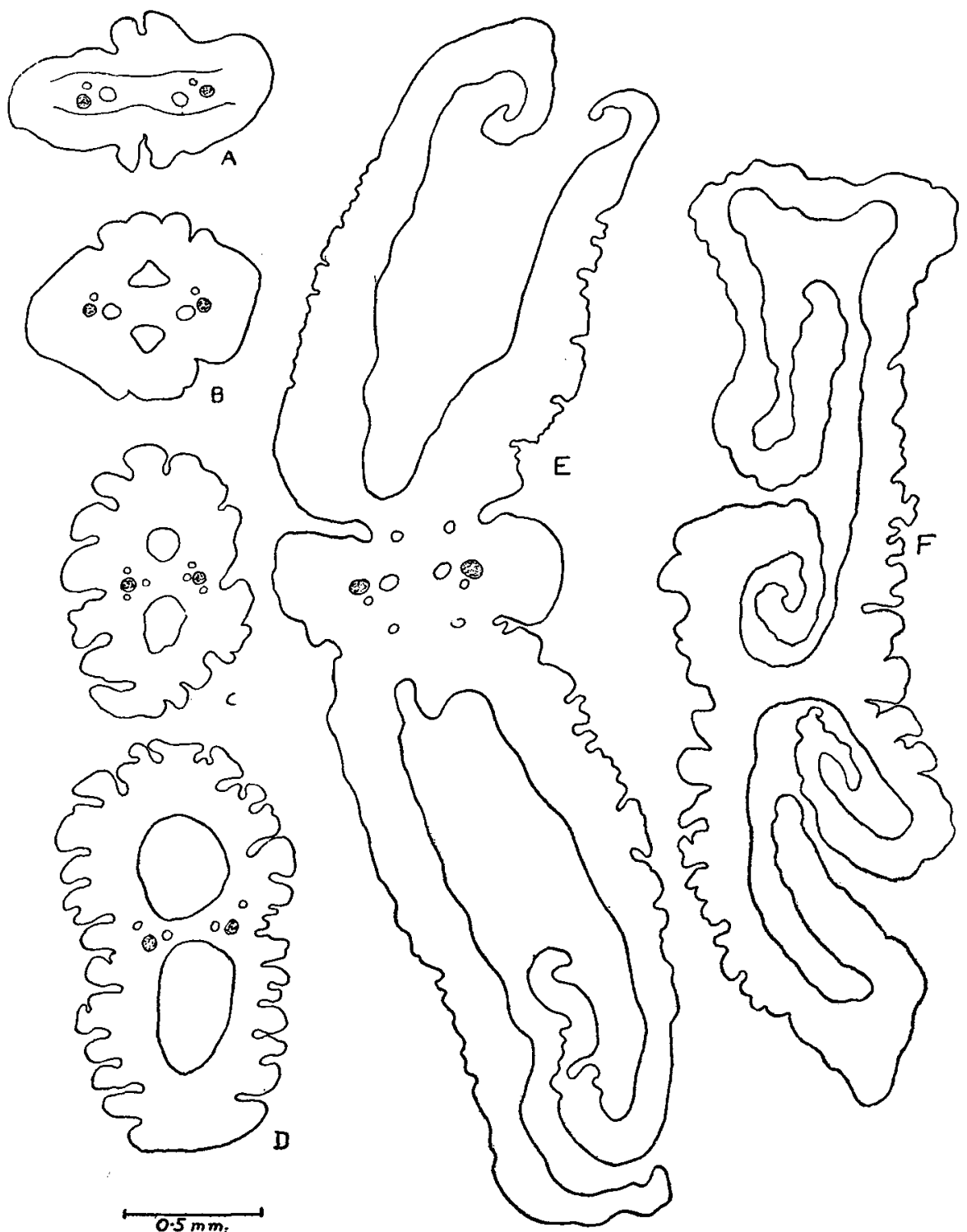

Fig. 6. Duthiersia fimbriata. $A-F$ transverse sections passing through different regions of the scolex, $A$, being nearest the base.

The lateral nerve stems lie between the ventral and the dorsal vessels; they are $52 \mu$ in diameter.

The male and female genitalia (Figs. 7 to 9) are of the usual Bothriocephalid type. There are about 120-160 testes occupying two lateral fields extending 
beyond the excretory vessels. There are no testes dorsal to the female genitalia, but a single row of testes is to be found immediately anterior to the cirrus pouch. Each testis is about $70-80 \mu$ in diameter. The cirrus pouch opens into a common genital atrium situated in the middle of the anterior half of the segment; it is $0.2-0.3 \mathrm{~mm}$. long and $0.19 \mathrm{~mm}$. in diameter. It contains besides a short cirrus a large vesicula seminis. The external vesicula seminis is very muscular and is of the usual type found in this sub-family; it measures $0.11 \mathrm{~mm}$. by $0.07 \mathrm{~mm}$. The vas deferens is much coiled and passes dorsally to the uterus. The vagina follows a fairly straight course in front of the uterus, passing to the

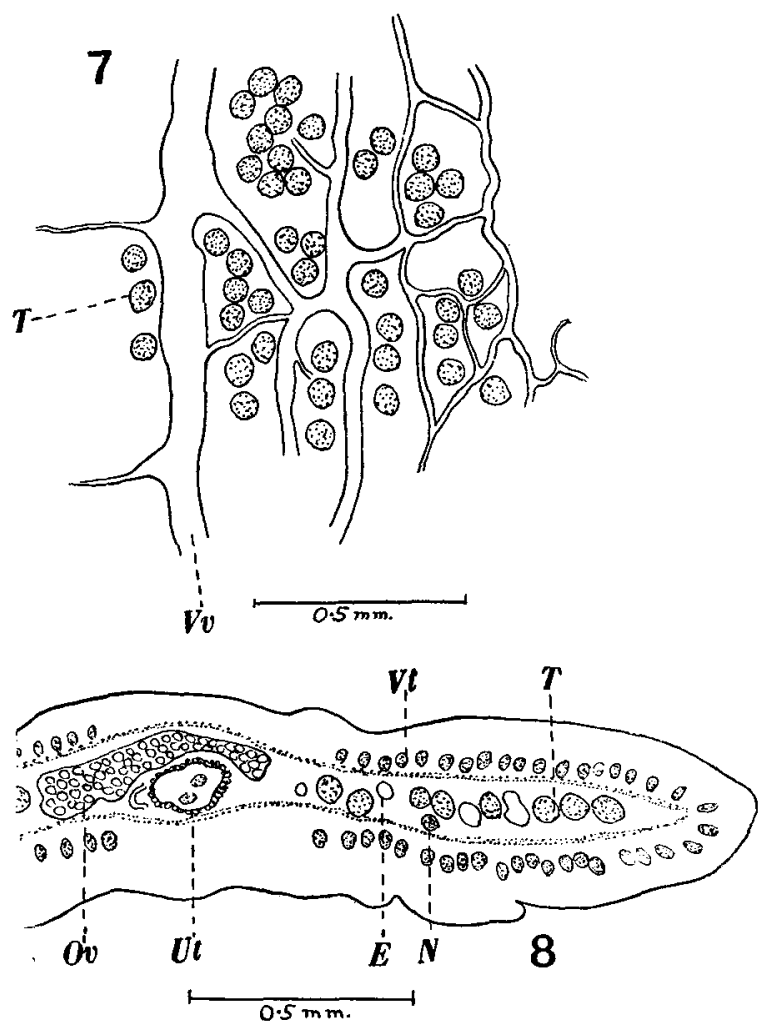

Figs. 7 and 8. Duthiersia fimbriata.

Fig. 7. Portion of a horizontal section showing the excretory system. Vv. Ventral vessel, $T$. Testes. Fig. 8. Portion of a transverse section. $E$. Excretory vessels, $N$. Nerve stem, $O v$. Ovary, $T$. Testes, Ut. Uterus, Vt. Vitellaria.

left or to the right of the uterine pore ${ }^{1}$. On reaching the ovary it forms a small receptaculum seminis which appears as a lateral swelling of the vagina. The ovary is fairly compact and is situated in the posterior half of the segment. We have never found the disposition figured by Klaptocz (1906) of the ovary in the shape of an $\mathbf{H}$. The vitellaria occupy two lateral fields in the cortex. These two fields are always separated from one another by the genital area.

1 There is a distinct sphincter vaginae. 
The oviduct is surrounded by a very small shell gland and leads almost immediately into the uterus. The latter is a coiled tube opening behind the genital atrium and generally in a line with the latter. Almost the entire uterus is surrounded by uterine glands. The regions in the vicinity of the uterine pore

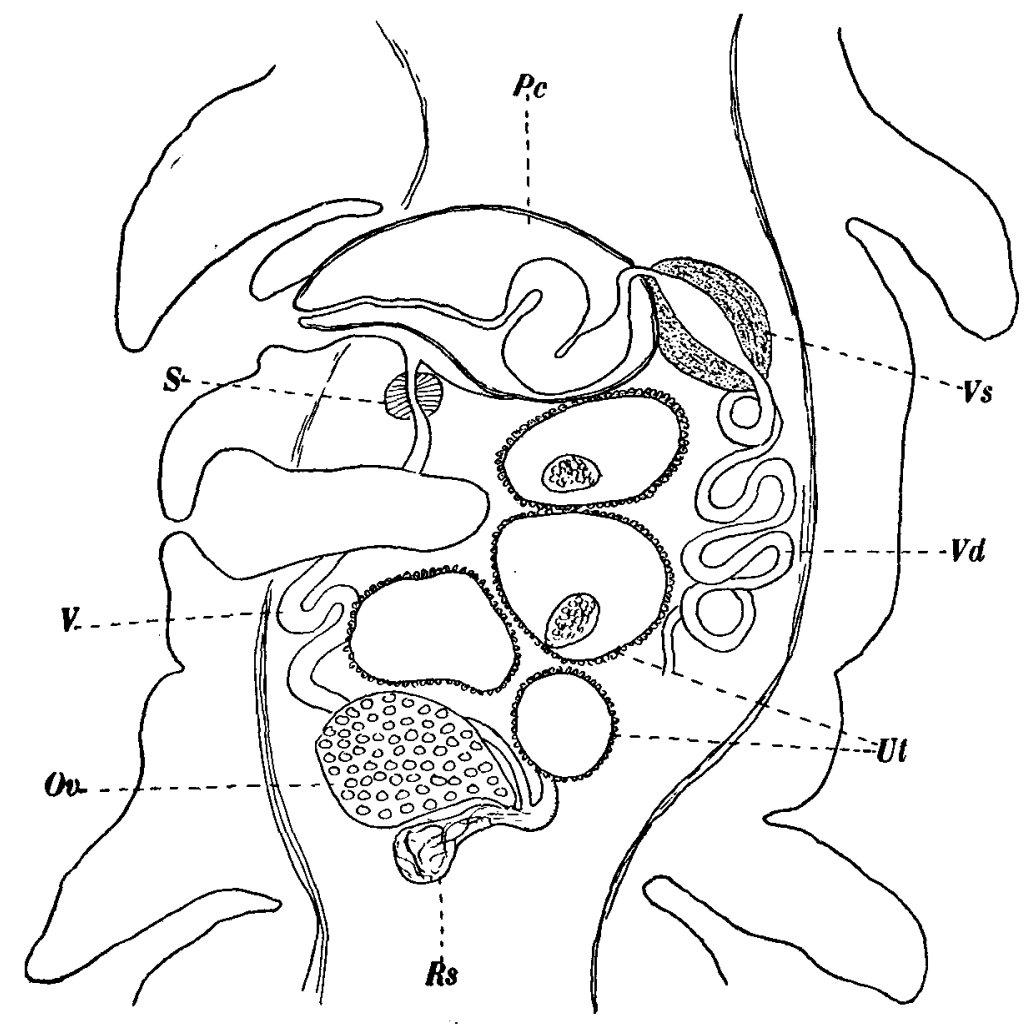

$0.25 \mathrm{~mm}$

Fig. 9. Duthiersia fimbriata. Sagittal section. Ov. Ovary, Pc. Cirrus pouch, Rs. Receptaculum seminis, $S$. Sphincter, $U t$. Uterus, $V$. Vagina, $V d$. Vas deferens, $V s$. Vesicula seminis.

and of the oviduct are alone devoid of glands. There are usually three to four uterine coils, the latter becoming dilated with eggs, especially in the region of the uterine pore. The eggs are operculated and measure $59-63 \mu$ by $37-44 \mu$.

(b) Proteocephalus niloticus (Beddard, 1913).

Among several specimens of $D$. fimbriata from Varanus niloticus captured at Dakar we have found numerous fragments of Proteocephalus niloticus (Beddard, 1913)1. (Figs. 10-12.)

1 We accept Woodland's revision of the genus Proteocephalus and consider the genus Acanthotaenia of biological but not of systematic interest. 
This species was first described by Beddard (1913a) from Varanus niloticus L. which died in the gardens of the Zoological Society of London. Beddard's description is totally insufficient and before comparing this species with the other known species we will first redescribe it.

It is difficult to determine the total length of this worm because of its great fragility - only fragments (the longest ca. $40 \mathrm{~mm}$.) being present, but we estimate the greatest length to be at least $50-60 \mathrm{~mm}$. The width of the strobila varies from $0.5-1 \mathrm{~mm}$. and most of the segments are either square or longer than wide. The limit between two successive segments is hardly visible either in whole mounts or sections. The only scolex found is $0.5 \mathrm{~mm}$. in diameter. The four suckers are cup-shaped and $0.13 \mathrm{~mm}$. in diameter. The fifth sucker is very well developed and $0.2 \mathrm{~mm}$. in diameter. The entire scolex is covered with minute spines which are also found on the suckers.

The musculature of the strobila presents several interesting features already described by Woodland (1925) for other species. The sub-cuticular musculature is well developed and consists of a single layer of stout longitudinal fibres and a layer of transverse fibres. This seems to be the only muscular system throughout the strobila. A parenchymatous musculature appears to be absent or invisible in our sections, so that the usual distinction of a cortex and a medulla cannot be made. The sub-cuticular cells are very distinct. The excretory system consists of the usual four longitudinal vessels, two dorsal and two ventral; the latter alone are visible in adult segments where most of the available space is occupied by the testes. The genital apertures alternate irregularly, the pore being situated a little in front of the middle of the edge of the segment. The cirrus pouch is $0 \cdot 19-0.2 \mathrm{~mm}$. in length, and $0.08-0.1 \mathrm{~mm}$. in diameter. It is pear-shaped and contains several coils of the vas deferens together with a long cirrus. The latter when fully extended measures $0.37 \mathrm{~mm}$. in length and $0.02 \mathrm{~mm}$. in diameter and is closely set with minute cuticular spinelets. As the cirrus alone is longer than the cirrus pouch it is obvious that it will be found coiled within the latter when not protruded. The vas deferens is extremely coiled, the coils lying in a mass in the middle of the segment between the vagina and the testes. The latter occupy a single dorsal layer limited laterally by the vitellaria and posteriorly by the ovary. There are about $45-60$ testes in each segment; they are large, measuring $74 \mu$ by $60 \mu$. The vagina opens generally in front of the cirrus pouch although we have often found the reverse disposition. The course of the vagina is that usually found in this genus and needs no comment (see Fig. 10). Certain structural details of the vagina deserve attention. The first part, extending from the pore to the middle of the segment, is thick-walled and lined with closely set setae. The vagina passes ventrally to the testes and dorsally to the uterus and to the ovarian isthmus where it joins the oviduct. In this part it appears somewhat dilated and sections show a distinct epithelial lining whose cells measure about $8 \mu$ and appear to be of a glandular nature. The ovary is fairly compact and measures $0 \cdot 6 \mathrm{~mm}$. across. The shell gland is situated behind and somewhat 
dorsally to the ovary. The uterus appears as a median tube which soon shows lateral outpocketings which increase in size and finally occupy almost the entire segment. In gravid segments there are about 12-20 lateral branches to the uterus. The vitellaria are situated on both sides of the segment and reach
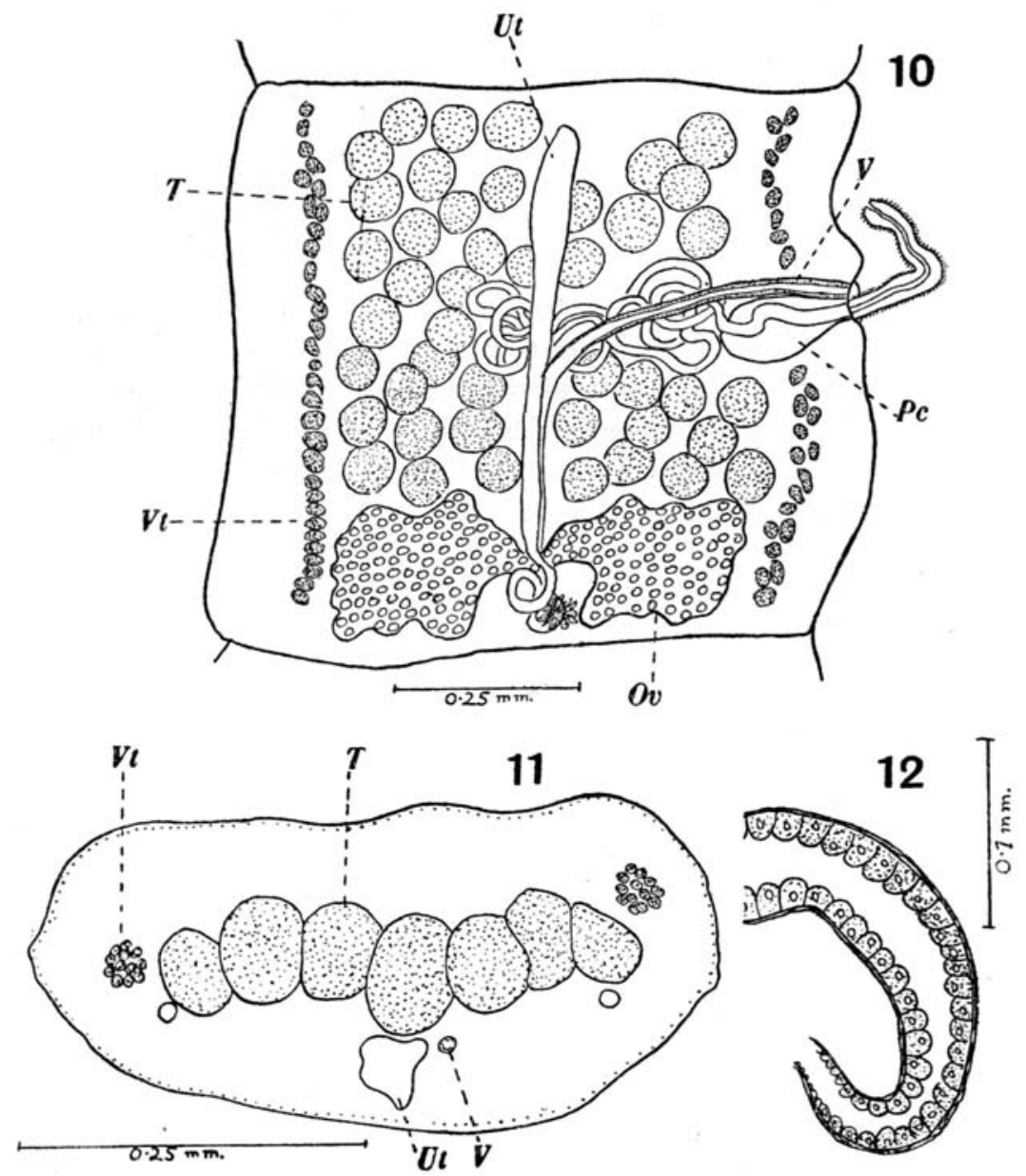

Figs. 10-12. Proteocephalus niloticus.

Fig. 10. General anatomy.

Fig. 11. Transverse section.

Fig. 12. Terminal portion of the vagina showing the glandular cells.

(Lettering as under Figs. 1-9.)

as far back as the ovary. The follicles are about $11 \mu$ in diameter. The ripe ova, i.e. those with a distinct shell, are spherical and measure $23-27 \mu$ in diameter. The embryo measures $15 \mu$ in diameter.

Up to now ten species of Proteocephalids have been described from monitors; they are $P$. articulatus (Rudin, 1917), P. continuus (Rudin, 1917), and $P$. niloticus (Beddard, 1913) from African monitors, P. beddardi (Woodland, 
1925), $P$. shipleyi (Linstow, 1903) and $P$. woodlandi (Moghe, 1926) from Indian monitors and $P$. biroi (v. Ratz, 1900), $P$. saccifer (v. Ratz, 1900), P. tidswelli (Johnston, 1909) and $P$. varius (Beddard, 1913) from Australian monitors.

If we now compare the three above-named species from the African monitor Varanus niloticus $\mathrm{L}$. we see at once that they are closely related, the following table facilitating comparison:

\begin{tabular}{lcccc}
\multicolumn{1}{c}{ Sength } & Width & Number of testes \\
and size &. \\
P. articulatus & 75 & 0.5 & $50-70,65$ & $0 \cdot 18$ by $0 \cdot 07$, cirrus armed \\
$P$. continuus & 200 & 1 & $60-80,80$ & $0 \cdot 14$ by $0 \cdot 08$, cirrus armed \\
$P$. niloticus & $50-60$ & 0.9 & $45-60,67$ & $0 \cdot 19$ by $0 \cdot 08$, cirrus armed
\end{tabular}

There seems to be no doubt as to the identity of $P$. niloticus and $P$. articulatus. The slight difference in the measurements are due to specific variability. The distribution of the testes is identical in both species and the average diameter of a single testis is nearly the same. We therefore consider $\boldsymbol{P}$. articulatus (Rudin, 1917) as a synonym of $P$. niloticus (Beddard, 1913). On comparing $P$. niloticus with $P$. continuus, the latter is found to differ from the former only in a few details, i.e. mainly in the size of the strobila, the testes being larger and more numerous, and the cirrus pouch being smaller. Are these differences sufficient to distinguish the species? Provisionally, $P$. continuus may be considered a good species until more material has been examined although it may well be but a forma major of $P$. niloticus. With regard to the Indian species, i.e. P. beddardi (Woodland, 1925), P. shipleyi (Linstow, 1903) and $P$. woodlandi (Moghe, 1926), P. shipleyi was described by Linstow (1903) from a single specimen with undeveloped uterus. His description is totally insufficient and renders any comparison difficult, yet we feel convinced that further study will show that $P$. woodlandi Moghe, 1926 is synonymous with $P$. shipleyi; $P$. beddardi on the other hand, although closely related to the preceding species, seems to present sufficient specific details to justify its systematic position.

Therefore the Indian and African monitors harbour very closely related species of the same genus of tapeworms. Further study on more ample material will no doubt prove that the Indian and African monitors harbour the same species of parasites.

The four species described from Australian monitors, viz. P. biroi (v. Ratz, 1900), P. saccifer (v. Ratz, 1900), P. tidswelli (Johnston, 1909) and P. varius (Beddard, 1913) ${ }^{1}$, are also closely related, although it is impossible to compare them fully because $P$. biroi, $P$. saccifer and $P$. tidswelli are insufficiently known. We are however convinced, that when more material has been examined, similar results to those above described will be obtained, and that the number of purported species of Proteocephalids from Australian monitors will be much reduced.

1 We do not agree with Woodland $(1925$, p. 379) when he states that the worm described by Nybelin (1917) is specifically different from that described by Beddard (1913). 
Woodland (1925) has recently given a list of the known species of Proteocephalus inhabiting the Varanidae; to this list we add P. continuus (Rudin, 1917).

\section{REFERENCES.}

Beddard, F. E. (1913). Contributions to the Anatomy and Systematic Arrangement of the Cestoidea. Ix. On six species of Tapeworms from Reptiles belonging to the genus Ichthyotaenia (s. 1). Proc. Zool. Soc. Lond. pp. 4-36, figs. 1-10.

- (1917). On the scolex in the Cestode genus Duthiersia, and on the species of that genus. Ibid. pp. 73-82, figs. 1-5.

Johnston, T. H. (1909). On a new Reptilian Cestode. Proc. Roy. Soc. N.S. Wales, xuII. $103-116$, figs. $1-6, \mathrm{Pl}$. vr.

Joyedx, Crr. and BAER, J. G. (1927). Recherches sur quelques espèces du genre Bothridium de Blainville, 1824. (Diphyllobothriidae.) Ann. Parasit. v. 127-139, figs. 1-5.

Klaptocz, B. (1906). Cestoden aus Fischen, aus Varanus und Hyrax. Sitzungsber. K. Akad. Wiss. Wien, math.-naturw. Klases cxv. 121-144, one Pl.

LA RuE, G. R. (1914). A revision of the Cestode family Proteocephalidae. Illinois Biol. Monogr. xII, No. 13.

Linstow, O. (1903). Drei neue Taenien aus Reptilien. Centralbl. f. Bakt. u. Parasit. Orig. xxxm. 532-535, figs. 1-7.

LüнE, M. (1899). Zur Anatomie und Systematik der Bothriocephaliden. Verhandl. deutsch. Zool. Gesell. 9 Vers.

- (1900). Beiträge zur Kenntniss der Bothriocephaliden. Centralbl. f. Bakt. u. Parasit. Orig. xxvII. 209-217, 252-258, figs. 1-3.

Moghe, M. A. (1926). Two new species of Cestodes from Indian Lizards. Rec. Indian Mus. XXVIII. 53-60, figs. 1-10.

Montichuli, F. S. and CRETY, C. (1891). Ricerche intorno alla sottofamiglia Solenophorinae Montic. et Crety. Mem. R. Accad. Sc. Torino, xLI. 381-402, one Plate.

Nybelin, O. (1917). Australische Cestoden. Kungl. Sven. Veten. Handl. LII. 1-48, figs. 1-5. Pls. I-III.

- (1922). Anatomische systematische Studien über Pseudophyllideen. Göteborgs Kungl. Veten. Handl. xxvI. 1-228, figs. 1-118.

Perrier, E. (1873). Description d'un nouveau genre de Cestoides. Arch. Zool. Exp. II. 349 362, Pl. Xvт.

Ratz, St. v. (1900). Trois nouveaux Cestodes de Reptiles. C.R. Soc. Biol. LII. 980-981.

Rudin, E. (1917). Die Ichthyotaenien der Reptilien. Rev. suisse Zool. xxv. 179-381, figs. 1-26, Pl. v-vIr.

Schwarz, R. (1908). Die Ichthyotaenien der Reptilien. Dissert. Basel.

ShIPLeY, A. E. (1904). Some parasites from Ceylon. Spol. Zel. I. 45-55, Pl. I.

Southwerr, T. (1913). On some Indian Cestoda. Rec. Indian Mus. Ix. 279-300.

Woodland, W. N, F. (1925). On three new Proteocephalids. Parasitol. xvII. 370-394, figs. 1-18.

(MS. received for publication 28. III. 1927.-Ed.) 